\title{
THE CONCEPT OF PENAL MEDIATION FOR DEFAMATION DELICT IN THE INDONESIA ITE LAW AS A MANIFESTATION OF RESTORATIVE JUSTICE
}

\author{
Yaris Adhial Fajrin ${ }^{1}$; Ach Faisol Triwjaya ${ }^{2}$ \\ 1Faculty of Law, Universitas Muhammadiyah Malang \\ 2Post Graduate Programe Faculty of Law, Universitas Brawijaya \\ Email: yaris@umm.ac.id
}

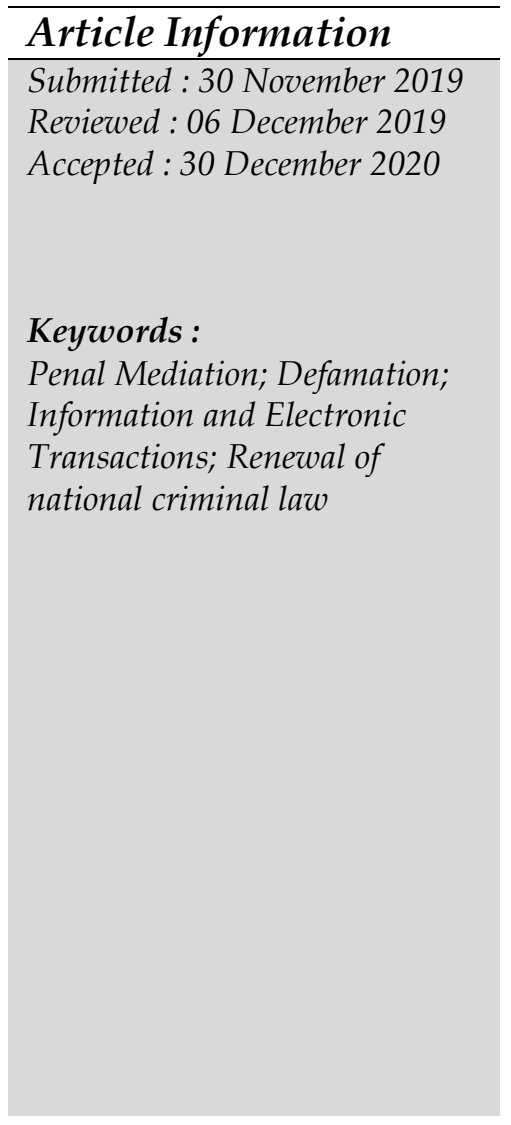

\begin{abstract}
The paper aimed to analyze the position of defamation as a complaint delict in the ITE Law and the chances of applying penal mediation in the settlement of criminal defamation charges in the ITE Law. This research uses a normative legal research with qualitative analysis techniques. The research result shows that defamation in the field of ITE is a complaint delict that the settlement of the case can be done through the Alternative Dispute Resolution (ADR) outside the court through penal mediation mechanism. The settlement of criminal cases through penal mediation has been in line with the direction of the renewal of Indonesian criminal law which is moving towards improving the impact of a criminal act as part of the purpose of criminalization. Penal mediation that promotes the values of consensus deliberation is also in line with the basic values of Pancasila, to encourage peace between the conflicting parties and improve the reputation, selfesteem, and dignity of victims damaged by defamation committed by the perpetrators. The advantages of penal mediation have not been followed by the rule of law of the event that regulates specifically the procedure of penal mediation so that not a few cases of defamation are ultimately decided by criminal sanctions to the perpetrators. Therefore, the mechanism of penal mediation needs to be regulated in the Indonesian Criminal Code in the future, to provide guarantees of a fair and beneficial criminal settlement for all parties, as well as a guarantee of the right to free responsible speech.
\end{abstract}

\section{Introduction}

The rapidly evolving technological advances have led people to more advanced, modern, and free civilizations and patterns of life or commonly referred to as the era of globalization. Changes in life patterns also have implications for communication patterns that are no longer done directly in the real world but can also be built online, one of which is through social media or can be called cyberspace. Such communication patterns and mechanisms ultimately triggered the awareness of one of the basic human rights, namely the right to freedom of expression and the right to free speech that covers up to the realm of free spee ch through social media. There is a problem if the right to 
human freedom is abused to exceed the boundaries of norms and rights owned by other human beings to attack the honour of a person, then that freedom can trigger conflict between parties. Looking at the social development of the community and the negative implications of conflict opportunities, the law in Indonesia has taken a role in dealing with changes through the Indonesia Law Number 11 year 2008 concerning Information Technology and Electronic Transactions jo. the Indonesia Law Number 19 year 2016 concerning Amendment to Law Number 11 of 2008 concerning Information and Electronic Transactions (hereinafter abbreviated as ITE Law). The existence of the ITE Law in the empirical level of law enforcement in Indonesia is not without weaknesses, because not a few cases related to defamation through social media are acted on using article 27 paragraph (3) of the law. Moreover, the defamation case is not least intended to provide criticism or input to the government or the authorities and responsible for the sectors of life-related to the problem of people's lives (public/public), so that the existence of these articles is seen as a means to curb the constitutional rights of citizens.

According to data from the Directorate of CyberCrime (Dittipidsiber) Republic of Indonesia Police Headquarters in the range of January to November 2020 the Republic of Indonesia Police has handled as many as 4,656 cases of cybercrime, of which 1.743 are defamation cases (CNN Indonesia, 2020). When compared to 2017 data of 1.451 cases, then in 2020 the number of defamation cases has increased (Mulyono, 2017: 161). This entity raises concerns that rigid and formal law enforcement will threaten the freedom of social media users in conveying their expressions in the form of writing and so on. An example of that is the case against Augie Fantinus, who was sentenced to five months in prison for allegedly committing defamation against police officers through social media (CNN Indonesia, 2018). The case has been a conciliation, but since it happened at the third hearing where the legal process had reached the examination process at the trial then the peace had no meaning because it could not stop the legal process. The mechanism of peace conducted informally outside the legal process seems futile and has no significant impact on the settlement of a criminal case.

The development of criminal law studies, especially regarding the relationship between perpetrators and victims, opens the possibility that a criminal act can touch the private sphere of the victim (Mulyadi, 2015: 2). With this in mind, it is necessary to think about including new concepts in criminal law, one of which is the mediation of penalties in defamation cases which are complaints delict in the ITE Law as an alternative means of settlement. Considering that the delict of the complaint itself allows the victim of a crime to play a role in determining whether a criminal case continues or not. The submission of the will to prosecution to victims or interested parties shows that there is an element of private relations in the sense of conflict resolution (Kumendong, 2017: 55). Through penal mediation, it is expected that it will be an alternative conflict resolution between the parties as an alternative dispute resolution (ADR) that has been developed in the form of legal thoughts and also as a guarantor of the freedom of citizens using cyber media without fear of the 
shadow of criminal sanctions that tend to be used arbitrarily. The concept that the author offers is also a manifestation of the renewal of Indonesian criminal law that wants to put forward humanism in law enforcement efforts as well as a means of solving criminal cases that provide benefits to the litigants.

Taking into account this background, the authors consider two problems, namely: first, what is the position of defamation as a complaint delict in the ITE Law? Second, what are the chances of applying penal mediation in the settlement of criminal defamation charges in the ITE Law? Several previous writings have been the inspiration and reference for the author in compiling this paper. First, a scientific article entitled "Mediasi Penal Dalam Sistem Peradilan Pidana Indonesia: Pengkajian Asas, Norma, Teori dan Praktik" (Penal Mediation in the Indonesian Criminal Justice System: The Study of Principles, Norms, Theory and Practice) written by Lilik Mulyadi in 2013, which discusses the basis and development of penal mediation in Indonesia (Mulyadi, 2013b). Second, a scientific article by Yusriando in 2015 entitled "Implementasi Mediasi Penal Sebagai Perwujudan Nilai-nilai Pancasila Guna Mendukung Supremasi Hukum Dalam Rangka Pembangunan Nasional" (Implementation of Penal Mediation as a Manifestation of Pancasila Values to Support The Supremacy of The Law in the Framework of National Development), which provides a study on penal mediation from the perspective of the value of Pancasila in the efforts to the Indonesian law building (Yusriando, 2015). Third, a scientific article by Galih Puji Mulyono in 2017 entitled "Kebijakan Formulasi Tindak Pidana Pencemaran Nama Baik Dalam Bidang Teknologi Informasi" (Policy formulation of Defamation Crimes in the Field of Information Technology), which discusses the issue of defamation in the field of ITE but only limited to the formulation policy (Mulyono, 2017). The three writings, as well as existing writings or scientific papers, have not discussed the issue of penal mediation for complaints delict, especially aimed at resolving defamation cases according to the ITE Law.

\section{Research Methods}

This paper uses normative juridical research methods that make legal norms as the main focus of its study. The approach used in this paper is the statutory approach and conceptual approach. The source of the law comes from the legislation, namely the ITE Law and scientific studies related to the theme of this paper. Analysis techniques used are qualitative, by deciphering legal materials that have been collected in a quality form of regular sentences, coherent, logical, not overlapping, and effective so as to facilitate in terms of interpretation and understanding of the results of the analysis. Then from the legal material the author did an analysis with the use of the theory relevant to the research. 


\section{Defamation as a Complaint Delict in The ITE Law}

\section{A. Anatomy of the complaint delict in the Indonesia Criminal Code and the ITE Law}

Simons calls a criminal act an unlawful act intentionally carried out by someone who can be held accountable for his actions so that the action is declared punishable by law (Lamintang, 2013: 185). Criminal act/delict as an immoral act according to the public view has two types of delict, namely absolute/ordinary delict (gewone delicten) and complaint delict (delicten allen op klachte vervolgbaar) (Lamintang, 2013: 218). An absolute delict is a delict that can be prosecuted without the condition of a complaint, while a complaint delict is a delict that can only be prosecuted if there is a complaint (Kumendong, 2017: 56). According to Von Lizt, the complaint delict objectively was due to direct losses which were protected, while according to memorie van toelichting (MvT) this delict was born as a result of the view that if the authorities were actively involved in the prosecution it would bring harm to the injured party so that the decision whether it was necessary to prosecute was left to the consideration of the person who feels wronged (Lamintang, 2013: 218).

There are two forms of complaint delict, namely absolute complaint (absolute klachtdelic) and relative complaint (relatieve klachtdelic). The absolute complaint is a complaint delict which requires a complaint as the main condition (voorwaarde van vervolgbaarheid) so that the perpetrator can be prosecuted, while the complaint delict is a relative requirement for delict to be able to sue if there is a special relationship between the perpetrator and the victim (Lamintang, 2013: 219). PAF Lamintang distinguishes between "absolute klachtdelict" and "relatieve klachtdelict" where absolute complaints are sufficient for the victim to mention the event only, while in the relative complaint must mention the event and the perpetrator (Lamintang, 2013: 219). The author identifies several distributions of complaint delict in the Indonesian Criminal Code, including Articles 284, 287, 293, 310, 322, 332, 367, 369, 370, 376, 394, 404, and Article 411.

The complaint delict, both relative and absolute, is a delict in which it has a private value/relationship between the parties involved (the perpetrator and the victim), or in other words, the personal loss due to a crime is greater than the loss of the general public. The Criminal Code regulates the complaint delict in such a way that it has its characteristics. The complaint delict in the Indonesia Criminal Code has the following provisions: first, a complaint delict in the Indonesia Criminal Code can be filed by a representative of a victim who has experienced a crime. Second, if the victim has died within the grace period (expiration), the heirs can file a complaint. Third, the grace period for complaint delict is six months if the victim is domiciled in Indonesia and nine months if the victim is domiciled abroad. Fourth, the Indonesia Criminal Code divides the complaint delict into two types, namely the absolute complaint delict and the relative complaint delict.

In the draft Indonesia Criminal Code (RKUHP) as an ius constituendum, the complaint delict is still regulated in the draft law, namely article 24 of the RKUHP states that in certain circumstances demands can be made on the condition that 
there is a complaint. Then regarding the criminal act that is included in the complaint delict or complaint crime must be clearly stated. Some of the complaint delict in the RKUHP include Articles 394, 417, 418, 440. The formulation of the articles regarding the complaint delict illustrates that the complaint delict is still a projection of steps in law enforcement against things that are considered a criminal act in Indonesia in the future.

Apart from the Indonesia Criminal Code, several rules outside the Indonesia Criminal Code regulate complaint delict, one of them is in the ITE Law. In general, the existence of criminal regulations outside the Criminal Code and the Criminal Procedure Code is needed because it sees the development of crime that is increasingly fast following the development of the times and human civilization, where it is not as fast as the development of law in Indonesia. Initially, this complaint delict was not recognized in Indonesia Law Number 11 year 2008, and it was not until Indonesia Law Number 19 of 2016 that the complaint delict was regulated, namely in Article 45 paragraph (3) jo. paragraph (5) which contains the following:

(3) Any Person who knowingly and without the right to distribute and/or transmit and/or make accessible electronic information and/or electronic documents that have a charge of contempt and/or defamation as referred to in Article 27 paragraph (3) shall be penalized with imprisonment of maximum 4 (four) years and/or a maximum fine of $\operatorname{Rp} 750.000 .000,00$ (seven hundred and fifty million rupiah).

(5) The provisions as referred to in paragraph (3) shall constitute of complaints delict.

The amendment is a follow-up to the Decision of the Indonesia Constitutional Court (MK) No. 50/PUU-VI/2008 and No. 2/PUU-VII/2009, which briefly explained the defamation delict contained in the Indonesia Law Number 11 year 2008 in principle the same as the defamation delict contained in the Indonesia Criminal Code. The court's decision is a correction to the Indonesia Law Number 11 year 2008, concerning the un-placed defamation as a complaint delict even though the two have similarities from the character of delict. Based on this fact, it should follow the defamation delict contained in the Indonesia Criminal Code as a whole, so that the author can underline that only one deliberation is categorized as complaints delict in the ITE Law, namely delict on defamation.

If using the principle of lex specialist derogat lex generalis, then the defamation in Indonesia Law Number 11 year 2008 had shifted its position to ordinary/absolute delict, which is a little bit of an impact on the mindset of the community and law enforcement when dealing with the issue of defamation, thereby prioritizing a formal legal approach that leads to criminalizing perpetrators. In fact, placing defamation as a complaint delict, according to Adami Chazawi, because this is an act that attacks personal interests, not society 
in general who is the victim like any other criminal activity (Chazawi, 2009: 169170). The Indonesia Criminal Code recognizes the crime of Humiliation, which is spread both inside and outside Chapter XVI of book II, thus distinguishing it into two forms of humiliation/contempt, namely general contempt and special contempt.

General contempt contained in Chapter XVI of Book II of the Indonesia Criminal Code, including: first, Oral Defamation (Article 310 paragraph (1)), second, written defamation (Article 310 paragraph (2)), third, Libel (Article 311), fourth, Mild Contempt (Article 315), fifth, Defamation Complaint (Article 317), sixth, false conjecture (Article 318), and seventh, Contempt of the deceased in Article 320-321 (Chazawi, 2009: 88). Compare with the formulation contained in the ITE Law indicated through the phrase "...contempt and/or defamation..." (...penghinaan dan/atau pencemaran nama baik...), which seems to separate/distinguish between insults and defamation, whereas according to the Indonesia Criminal Code of defamation is one part/type of insult/contempt delict. The formulation of Article 45 paragraph (3) of the ITE Law can be interpreted: contempt (which is classified as a general insult) and/or (in particular) defamation. The formulation of such a phrase, according to Adami Chazawi, must be proven in advance one type of contempt as stated in Chapter XVI Book II of the Indonesia Criminal Code because it remembers the principle of lex specialist derogat lex generalis (Chazawi, 2009: 291-292). In order to clarify the terminology used by the author, we use the term "defamation" as a sub-object of research, because it is related to the formulation contained in the ITE Law.

Defamation is a criminal offence that has the characteristic of harm to a person's personality so that it is classified as a criminal offence of public humiliation or general contempt delict. The opinion is based on the fact that the current the Indonesia Criminal Code separates two types of insult/contempt delict namely general contempt and special contempt, in which for insults related to self-esteem or honour concerning a non-person (class social or communal) is classified as a special contempt delict (Chazawi, 2009: 170), such as contempt of a particular group of residents (Article 156), or against religion (article 156a). If it is associated with the formulation contained in the ITE Law that lex spescialis, then defamation according to Article 45 paragraph (5) is a complaint delict, which distinguishes it from the special contempt delict that are ordinary/absolute delict.

The existence of law until now recognizes the existence of two kinds of laws, namely public law and private law. Criminal law is in the category of public law because it is greater to regulate a person's relationship with society in general. While private law is more regulating on matters of a personal nature, including civil law. Although criminal law is a public law there are some things in the rules that are nuanced personal/private values that give rise to the formulation of complaints delict, including delict about insults or defamation. This implies the completion of the case which can be resolved through a process proper to private law. Civil law (as one representation of private law) recognizes two types of litigation, namely litigation and non-litigation. Litigation is defined as dispute 
resolution through court lines, while non-litigation is an out-of-court dispute settlement (one of which is through means of mediation). Considering the character of complaints delict in criminal law that has a personal/private nuance in it, then the criminal acts can be resolved through means like civil law. The author's opinion does not differ much from that expressed by Mudzakkir, who placed violations of the category of complaints delict, both absolute and relative, as one of the characters of cases that can be resolved out of court or non-litigation (Mulyadi, 2015: 5).

\section{B. Defamation as a Complaint delict in the ITE Law: Opportunities to Achieve the Value of Justice In the Perspective of Indonesia's criminal law reform.}

The general explanation of Indonesia Law Number 19 year 2016 states: The affirmation of complaints delict is intended to be in line with the principle of legal certainty and a sense of community justice ("Penegasan mengenai delik aduan dimaksudkan agar selaras dengan asas kepastian hukum dan rasa keadilan masyarakat") so that if talking about the issue of defamation as a complaint delict in the ITE Law, it will not be separated from the values of justice to be achieved. The provision also reminds about the essence of legal objectives according to Gustav Radbruch that prioritize the purpose of justice over the purpose of benefit and also the purpose of legal certainty (Fajrin \& Triwijaya, 2019: 736), or as stated by Achmad Ali as a casuistic priority theory that applies priority to legal objectives by paying attention to the case by case (Ali, 2012: 213). Achmad Ali also stated about the purpose of law according to the eastern nation/Asia (theory of the purpose of eastern law) which emphasizes more on the principle: justice is harmony and harmony is peace (Ali, 2012: 212). The principle of justice is seen as in line with the principle of justice according to the philosophy of Pancasila as the foundation of Indonesian ideology that demands a balance and harmony between the interests of individuals, communities, nations, and countries (Fajrin \& Triwijaya, 2019: 736).

The grounding of the values of Pancasila justice in criminal law is an attempt to reform Indonesian criminal law, as Barda Nawawi Arief argues, that the reform of criminal law is a review of the basic points of thought and ideas adapted to Pancasila as the basic footing of the conception of renewal (Wahyuningsih, 2014: 20-21). The values in Pancasila as the vision of the state have historically been a crystallization of the living values of the Indonesian nation, which contains religious values/godhead, humanity, nationality, democracy (deliberation/discussion), and social justice. Indonesian society whose cultural roots are oriented towards the value of family culture that puts forward the principle of consensus deliberation to resolve a dispute in a social system, or in other words the dimension used is the dimension of local wisdom of customary law. The concept of justice in the form of balance restoration according to Barda Nawawi Arief includes; first, mono-dualistic balance; second, balance the interests of the victim and the perpetrator; third, objective (deed/act) and subjective balance (legal subject); fourth, the balance of legal certainty, 
flexibility, and fairness; fifth, the balance of national values and global values (Maerani, 2015: 334).

Criminal law will lead to criminal sanctions, as stated by Herbert L. Packer that criminal sanctions are the primary guarantor and at the same time as the primary threat or is the best means of dealing with crime. Become a primary threatener if criminal law is used indiscriminately without carefulness and inhumanely (Mulyadi, 2015: 62). Moreover, the influence of retributivism on classical schools is still very thickly used in the criminal justice system in all parts of the world including in Indonesia, so that it has negative implications for the neglect of the rights of victims and society because it views crime as a violation of the interests of society/state, not a violation of the interests and rights of victims (Mulyadi, 2015: 64). The direction of the renewal of Indonesian criminal law began to view criminal law with its criminal sanctions as a means of socializing and reintegrating perpetrators into society. This is illustrated in the formulation of Article 51 of the RKUHP on the purposes of criminalization, namely: first, preventing criminal acts by enforcing legal norms for the sake of public service; second, socialize the convicted by conducting coaching so that he becomes a good and useful person; third, resolve conflicts arising from criminal acts, restore balance, and bring peace to society; and fourth, free the guilt of the convicted.

The direction of the ideal of reforming the national criminal law is also in line with the development of modern criminal law in the world, which views criminal law with its sanctions that have a negative effect, both on perpetrators, victims, and society. This then gave rise to the idea of what is called restorative justice. Braithwaite and Strang, explain that Restorative Justice can be seen in two senses. First, restorative justice as a concept of process, namely bringing together the parties involved in a crime (perpetrators, victims, and society) to express suffering and measures taken to recover; and second, restorative justice as a concept of value, then this restorative justice contains values that focus on recovery, not on condemnation (Sullivan \& Tifft, 2006: 555-556). Not much different, Muladi also explained that restorative justice is aimed at empowering victims, perpetrators, families, and communities to correct an act against the law by using awareness and insanity as a foundation to improve people's lives (Laksana, 2017: 60-61).

The concept of restorative justice is in line with the direction of reform of Indonesian criminal law which leads to the return of balance due to the occurrence of a crime and is also in line with local values that develop in Indonesian society. This is because the framework of a restorative justice approach involves perpetrators, victims, and the community in an effort to create a balance between perpetrators and victims (Lasmadi, 2011: 2). Therefore, the essence of restorative justice is healing, moral learning, community participation and attention, dialogue, forgiveness, responsibility, and making changes (Tarigan, 2015: 109). The basic principles of restorative justice find its footing in the value of Pancasila which upholds the value of balance and benefit to both the 
perpetrator and the victim, in order to realize the ideals of social justice for all Indonesian people.

The view of restorative justice is slowly starting to have implications for the criminal justice system in Indonesia. Considering that there are several criminal offences that are included as complaint delict in the Indonesia Criminal Code and beyond, even these complaints are still known in the RKUHP as the author has described in the previous discussion. Taking into account the character of the complaint delict which protects personal interests, it is possible for the criminal defamation crime in the ITE Law to be resolved through channels other than criminal law, just like civil law. This settlement is known as the Alternative Dispute Resolution (ADR), one of which is known as the penal mediation model. Moreover, in the RKUHP Article 72 letter d, which regulates the reasons for the failure of the prosecution, namely if there is a settlement outside the process. This indicates that the out-of-procedure settlement or ADR for criminal cases is one of the ideals of Indonesian criminal law in the future.

\section{The Prospect of Penal Mediation as an Alternative to Resolve Defamation Cases in the ITE Law}

1. Penal Mediation as Alternative Disputes Resolution (ADR) in Line with The Renewal of Indonesian Criminal Law

Alternative settlements are generally known in civil law (as a representation of private law), as is the provision of the Indonesia Law Number 30 year 1999 concerning Arbitration and Alternative Dispute Resolution, which requires mediation first. As for criminal law which is a representation of public law is not possible mediation, but according to Barda Nawawi Arief, it can be possible to apply to certain crimes that are complaints delict through the retraction of related case reports (Arief, 2008: 2-3). Noting that there is room for complaints to be resolved outside the court, it raises the idea of penal mediation for criminal cases.

Moreover, Indonesia still recognizes the existence of a customary legal system in empirical level in society, as Otje Salman Soemadiningrat sees from the number of judges whose rulings are based on customary criminal law, because (Mulyadi, 2015: 51): first, customary law does not recognize the existence of a firm separation between criminal law and civil/private law; second, customary sanctions can be in the form of compensation by violators to the affected parties as a result of such violations; and third, customary law is always related and contains elements of culture and beliefs. This opinion is quite relevant if it is correlated with the social context of Indonesian society which in its history of development does not distinguish between criminal law and civil law (or between public law and private law) so that any dispute or conflict that occurs allows to be resolved outside the criminal channels including by mediation (Mulyadi, 2015: 6).

Looking at the development of criminal law, criminal sanctions and criminalization aim to protect the parties to find justice and benefit. Such 
developments encourage a paradigm shift in the settlement of criminal cases in Indonesia in line with the renewal of criminal law, which must adjust to the international development that has been agreed by civilized society (Yudianto, 2016: 41), and must pay attention to the values or unwritten laws that have lived, grown, and developed in Indonesian society, as the theory of legal development proposed by Mochtar Kusumaatmadja (Aulia, 2018: 357). Furthermore, Sudarto's opinion, which relates to political factors in law development, which relates to the idea of legal integration following the insights of the archipelago/Wawasan Nusantara (Santoso, 2015: 17), so that it is in line with the opinion of Eugen Erlich who stated: "the centre of gravity of legal development lies not in legislation not in juristic science, not in a judicial decision, but in society itself." (Mulyadi, 2015: 9). What the legal experts say above shows that laws that are good for a particular social configuration are those that thrive in that social configuration.

Penal mediation in Indonesian society is not foreign/new. This is illustrated by the principle of consensus deliberation (musyawarah mufakat) that has been lived within the Indonesian people, which becomes the main foundation and takes precedence in any settlement of disputes in Indonesia, including criminal cases (Mulyadi, 2013: 4-5). The existence of this principle as the soul of the Indonesian people that existed for a long time, then appointed in the embodiment of the 4 th principle of Pancasila. Local wisdom of customary law according to Soepomo is defined as a living law because it incarnates the real legal feelings of the people, is dynamic and will grow and develop in line with the development of its society (Mulyadi, 2013a: 231), or by Carl von Savigny called it the term soul of the nation or volkgeist (Mulyadi, 2013b: 5). In practice, the basic manifestation of consensus deliberation is described in various cultures of Indonesian society, such as "bakar batu" culture in Papuan society (Yusriando, 2015: 26), "gampong" judiciary in Aceh society, traditional institutions in "awigawig" in Balinese society, or "begundem" institution in the NTB society (Mulyadi, 2013a: 228-229). The description can give an idea that penal mediation has long been practised by the Indonesian nation in resolving criminal disputes, so it is not wrong if Marc Levin stated that the approach that was once declared obsolete, ancient, and traditional (referred to as restorative justice approach in the form of ADR or penal mediation) is now stated as a progressive approach (Rumadan, 2013: 273).

Penal mediation can be interpreted as mediation known in civil law, namely the activities of the two parties who have efforts to produce an agreement. The difference lies with the parties (perpetrators/offender and victims), and the type of dispute that becomes the object of mediation (the object of mediation penal deeds classified as criminal acts). Mark Wiliam Braker stated that penal mediation is a process of resolving criminal cases by bringing together perpetrators and victims to reach a mutual agreement related to crimes committed by perpetrators and restitution given to victims (Faisal, 2011: 83). There are various terms regarding penal mediation, including mediation in criminal cases or mediation in criminal matters, which in Dutch is called "strafbemiddeling", or in French it is called "de mediation penale", or often referred 
to as victim-offender mediation (VOM), or offender victim arrangement (OVA). (Faisal, 2011: 83)

The veracity of Marc Levin's opinion is also based on current facts, in which the development of criminal law in several countries as well as globally leads to the use of ADR. The author's opinion can be seen from the emergence of various international agreements, as follows (Mulyadi, 2013b: 5): first, The 9th United Nations Congress in 1995, specifically on criminal justice management (document A/CONF.169/16). In order to overcome the problem of excess case accumulation in court, the congress participants emphasized efforts of conditional release, mediation, conciliation, restitution, and compensation especially for novice actors and young actors; second, The International Penal Reform Conference on 13-17 April 1999 stated that one of the key elements of the criminal justice reform agenda is the need to enrich the formal justice system with an informal system or mechanism, by identifying nine strategies in the reform of criminal law, including restorative justice, ADR, informal justice, reducing the prison population, and the role of civil society in penal reform; third, The 10th UN Congress in 2000 (document A/CONF.187/4/Rev.3), on providing protection to victims should be instructed by restorative mediation and justice mechanisms; four, The EU made the EU council framework decision on the standing of victims in criminal proceedings on 15 March 2001; fifth, The UN Principles of 2002 (ECOSOC resolution 2002/2012) on Basic Principles on the use of restorative justice programmes in criminal matters.

The use of penal mediation has also been implemented by several countries (Mulyadi, 2015: 17). First, Malaysia is familiar with the term banking mediation, so penal mediation covers banking disputes due to unauthorized ATM or credit card withdrawals. Second, Thais who know the deliberations of family groups. Third, Laos often uses penal mediation as a medium of re-education on customary law. Fourth, Papua New Guinea, which recognizes the Diversion Law of 1991. Fifth, the Philippines, which applies diversion to child criminal cases (Harefa, 2015: 10). Seventh, laws in several European countries such as Austria, Germany, Belgium, France, Poland, Latvia, the Netherlands, and also the United States (Mulyadi, 2013b: 5). As for Indonesia, the author identifies several rules that can be used as the legal basis for the application of penal mediation, namely (Mulyadi, 2013b): first, Article 18 paragraph (1) of Indonesia Law Number 2 year 2002 concerning Police; second, the Indonesia Law Number 11 year 2012 concerning the Juvenile Criminal Justice System; third, Chief of Republik of Indonesia Police Letter Number Pol: B/3022/XII/2009/SDEOPS dated December 14, 2009, concerning Case Handling Through Alternative Dispute Resolution (ADR); fourth, Chief of Republik of Indonesia Police Regulation Number 7 year 2008 concerning The Basic Guidelines for Strategy and Implementation of Community Policing in the Implementation of Police Duties; and fifth, the Decision of the North-East Jakarta District Court No. 46/Pid/78/UT/WAN dated June 17, 1978.

Lilik Mulyadi explained that the regulation on penal mediation is still part and limited, and the gradation of the arrangement is set at a level under the law 
(Mulyadi, 2015: 40). The Indonesia Law Number 11 year 2012 concerning the Juvenile Criminal Justice System, is limited to the handling of cases that position children as perpetrators of crimes in the form of diversion efforts. There is also jurisprudence as one of the sources of law in Indonesia, but it does not touch up to the technical level and formal. Looking at these matters, one of the legal problems in Indonesia is the absence of written rules at the legal level governing penal mediation and ADR. Several the Indonesia Supreme Court Decisions integrate customary settlements into settlements by the State. For example, in the Decree Number 1644K/Pid/1988 dated May 15, 1991, which shows that customary sanctions are not only about the arrest of the perpetrators but in which there is deliberation until the payment of a number of customary fines. The ruling could also be considered as a recognition of penal mediation in the country's criminal justice system.

When talking about the technical implementation of penal mediation, theoretically know there are several models, namely: Victim offender mediation (VOM), Family and Community Group Conferences, Informal Mediation, and traditional village or tribal moots models. Based on all these models, Stefanie Trankle formulated the working principle of penal mediation, namely (Arief, 2008: 5-6): first, handling conflict through the involvement of the parties in the communication process; second, the mediation process with the communication process of the perpetrator, victim and third party will be able to realize the perpetrator of his mistakes and calm on the side of the victim from fear; third, mediation processes that are not bound by rigid legal procedures; and fourth, the active participation of the parties, especially the victim is given space to convey his will.

Penal mediation when reviewed philosophically, is aimed at finding justice that is win-win to the parties. The purpose of the win-win here is to achieve the highest justice, namely the agreement between the perpetrator and the victim so that it affects the loss of the victim's grudge to the perpetrator due to the suffering experienced and the revenge of the perpetrator against the victim when the perpetrator feels the punishment is not comparable to his actions. Through this mechanism the victim can request restitution from his/her loss to make excuses, or the victim to excuse the perpetrator when the perpetrator has made an apology to the victim for his actions (Mulyadi, 2013b: 3). Penal mediation as an alternative to the settlement of criminal cases in line with the objectives of criminal renewal, especially to resolve conflicts caused by criminal acts, restore balance and bring peace in society. Then, if analyzed from the perspective of the philosophy of criminalization based on Pancasila, penal mediation will achieve results to socialize the perpetrator and protect the victim from fear as a continuation of his suffering. Penal mediation is also beneficial to the judicial process that upholds the principle of a fast, simple and light-cost judiciary.

\section{Prospect of Penal Mediation as ADR for Defamation Crimes in ITE Law}

Technological advances have brought about a change in the pattern of opinion as a constitutional right of citizens. Through cyber media, it is possible 
to express opinions, as well as criticism. This progress was responded by the state through ITE laws and more specifically in criminal defamation to create conducive conditions in using cyber technology. Criminal defamation is a criminal offence that has a four-person relationship (the perpetrator with the victim) in it, so the crime is categorized as complaint delict. Complaint delict is nuanced personal/private (because of the dignity and honour that is attacked by the perpetrator), then it is the entrance for mediation penal. As Barda Nawawi Arief argued that for criminal complaints (complaint delict) it can be possible to apply penal mediation as an alternative solution, through the retraction of related case reports. This is seen as more useful in resolving conflicts as is the purpose of Indonesia's criminal law (and criminalization) within the framework of renewal.

Formal legal settlements for defamation cases, especially in the field of ITE, can cause conflict between the litigants will continue, where the purpose of "remorse" of the perpetrator and "forgiveness" of the victim is very difficult to achieve through formal means of criminal law. Besides, if criminal acts (including defamation) should lead to prison sanctions tend to provide negative social stigma that inhibits ex-convicts in their efforts to socialize and reintegrate with the community (Mulyadi, 2013b: 6). Therefore, there is no harm in what Muladi said, where the model of resolving cases that are considered to cause new conflicts must be replaced with a model that reduces conflict, namely with dialogue between the disputing to solve the problem is a very positive step (Mulyadi, 2015: 203). The family approach based on consensus deliberation is what appears in the ADR model in the frame of restorative justice so that the court is placed in the position of the mediator (Sahabuddin, 2014: 172).

Moving on from Lilik Mulyadi's opinion on the advantages of penal mediation in general, it can also be an advantage in the settlement of defamation cases in the field of ITE. These advantages are as follows:

\section{i. Reduce feelings of resentment and re-harmonize the parties involved in disputes.}

According to Stephenson, Giller and Brown, restoration justice aims to improve crime by balancing perpetrators, victims, and communities in the form of penal mediation (Nisa \& Jaya, 2020: 258-259). Restorative justice approach through penal mediation in criminal law has the power to restore relations between disputing parties while preventing deeper hostilities and encouraging voluntary reconciliation between parties (Sunarso, 2012: 157). As stated by Stefanie Trankle above, where penal mediation emphasizes more on the pattern and good way of communication between the parties, namely the perpetrators and victims and even the community, with the state as mediators and facilitators.

This pattern, known by the Indonesian people as the basis of consensus deliberation, gives rise to mutual openness between the parties. The disputing parties, together with the people and the state sit together, face to face, meeting to jointly resolve disputes, until the discovery of a joint solution in the form of a win solution. The essence of this pattern of communication is to seek mutual benefit in the form of remorse by the perpetrator, and 
forgiveness from the victim and his family, as well as a means of community and state participation in resolving a criminal case so that the same thing does not happen again or again to the same or different perpetrators and victims. Siswanto Sunarso calls it a human and humanitarian approach (interhuman) so that the criminal law and its judiciary can benefit all parties (Sunarso, 2012: 156).

The author further cites the opinion of Adam Graycar who attributes this restorative justice approach to criminology views (Lasmadi, 2011: 3). According to him, restorative justice needs the support of the theory of reintegrative shaming (the theory quoted from Braithwaite), so that there are two things inherent in the penal mediation process, namely: first, to achieve the success of the reintegration, the presence and participation of the community are needed for the support of perpetrators and victims; and secondly, the process requires shaming as a confrontation for the perpetrator's misdeeds. Both of these things are intended to explain to the perpetrator that the act is a despicable act in the community, as well as support and respect for a perpetrator even though his actions are despicable. The pattern of communication between the disputing parties and by being associated with Adam Graycar's opinion above gives the author an idea of the concept of penal mediation in the defamation case in the field of ITE. Remorse or guilt of the perpetrator can arise when met with the victim, with also attended by law enforcement and community representatives. The meeting and communication pattern as described can provide an understanding of the perpetrator that the act is a defamation that is despicable in the community and can harm the victim.

The perpetrator's remorse can be realized in the form of clarification and public apology, especially in ITE-based media where the perpetrator disseminates writings/images containing elements of defamation of the victim. This solution model is considered worth it because it gives a double effect in the resolution of the dispute, namely: first, by publicly apologizing as a form of clarification and regret, will provide separate social sanctions for the perpetrator, and second, as an anticipatory effort and improvement of the impact that can be caused by the defamation in the form of destruction of the dignity and honour of the victim in front of the community of his social environment. These two things (as the author calls the double effect) can have implications for the re-harmonization of the relationship between the two parties (the perpetrator and the victim, and their families) so that this dispute does not continue until the greater family level (the next child/further descendants) in the future. The harmonious form of relationships is not only for victims, perpetrators, and families but also for the community, where it can minimize the occurrence of vigilantes/"main hakim sendiri" or in the context of ITE is called cyberbullying against perpetrators, victims and their families.

The concept of penal mediation against defamation cases in the ITE field is not much different from what has been practised in the UK. As part 
of public law, the settlement of defamation cases in the UK has a different resolution mechanism, where a person who is deemed to have committed defamation is allowed to make an apology to the victim by making a written and published statement and compensating the victim with a mutually agreed amount (Tami \& Jaya, 2013: 116).

ii. Provide opportunities in the form of compensation/restitution to victims as a substitute for criminal sanctions.

Compensation in criminal law is given to the victim or his heirs (Article 98 to 101 the Indonesia Criminal Procedure Code). Compensation for victims of criminal acts, until now only applied only to victims who suffered material losses. Several laws and regulations outside the Indonesia Criminal Code regulate indemnities, such as in the Indonesia Law Number 13 year 2006 concerning The Protection of Witnesses and Victims jo. the Indonesia Law Number 31 year 2014 concerning Amendments to Law Number 13 year 2006 concerning the Protection of Witnesses And Victims. The issue in the witness and victim protection law governs the provision of restitution or compensation to victims not integrated into the criminal justice system. The criminal code bill provides for additional criminal damages, meaning that the awarding of compensation does not remove the prison sanction because it follows the main criminal, so it is given through court decisions.

ITE Law itself does not regulate the form of sanctions in the form of compensation to victims, so by paying attention to the principle of lex specialis derogat lex generalis, it is not known the existence of compensation for victims of defamation in the field of ITE. Paying attention to this, as well as paying attention to defamation as a complaint delict, opens the possibility of an agreement on the provision of restitution paid by the perpetrator to the victim, through the means of penal mediation. Indemnity, in this case, can be material or immaterial, where specifically for the object of defamation (in the form of self-esteem, dignity, and honour attacked) which is spiritual/ immaterial then it is necessary to use a consensus approach to find a meeting point about the amount of compensation to be paid by the perpetrator, as compensation from the crimes that have been committed. The provision of compensation through the concept of penal mediation allows the provision of compensation outside the procedural law of the event as is still practised today in several laws and regulations.

\section{iii. More flexible because it does not have to follow formal criminal justice procedures.}

One of the characteristics of criminal law is the way it is enforced through the mechanism of the criminal justice system and prevents individual settlement so that mediation cannot be carried out, but it is excluded for certain crimes (Arief, 2008: 2-3). According to Mudzakir, certain crimes referred to in this case include cases that fall into the category of complaints delict (Mulyadi, 2013b: 2). Settlement through penal mediation can be legally recognized as a criminal settlement because the case has been resolved so there is no legal reason to file the case to the court. 
iv. Cost is more efficient, a fast process than through the judicial process.

The judiciary as a litigation institution becomes a last resort when dispute resolution cannot be resolved by consensus. The compromise approach aims to find a meeting point between different interests until an agreement is produced. This kind of process will take a short time so that it has implications for the bloating of costs borne by the parties. This empirical fact contradicts one of the principles contained in the Indonesia Procedure Code which is simple, fast and light cost. The principle if applied will provide comfort for people who seek justice, because if the principle is applied everyone will be entitled to the recognition, guarantee, protection and certainty of fair law and equal treatment before the law (Sihotang, 2016: 3).

Based on J.J. Bruggink's opinion that the principle of law as a meta-rule that contains a measure of value and does not directly provide guidelines (Respationo \& Hamzah, 2013: 104) (Saripudin, 2010: 20), then the application of simple principles, fast and light costs can be done through mediation mechanisms in the settlement of criminal law conflicts. A concrete form is based on the pattern owned penal mediation in the form of communication patterns conducted between parties attended by mediators, so it is expected not to reach the trial that takes a long time and costs are not small. Through penal mediation, it will be possible to find a word of an agreement to make peace because it is a forum aimed at eliminating resentment, and a forum for the recovery of the parties.

v. Reduce the burden of case accumulation at the police, prosecutors, and courts, especially on the issue of overcapacity in correctional institutions.

Currently found the fact of the large accumulation of cases from the stage of investigation (police) to the court (judiciary). For example, at the level of an investigation, there are about 160,000-180,000 cases that each year fail to be upgraded to prosecution (Iswara, 2017: 26). This phenomenon shows that the condition of the Indonesian legal system is not ideal because the ideal contained in the principle of fast, simple and light justice are not achieved in the regulatory level and have an impact on the application.

Not only that, but problems also occur in the realm of criminal implementation, namely the overflow of the inmates of correctional institutions when compared to the supposed capacity (over-capacity). The problem can be addressed through the application of penal mediation which is part of restorative justice that avoids the punishment of bodily (Kantianism), thereby also impacting the reduced population of correctional institutions. While the process of resolving the complaint delicts stops in the mediation phase penal, will have an impact on the non-criminalization of an offender in prison so that it will have a reduced impact on the inmates of the correctional institution.

vi. Guarantee for cyber media users from the threat of arbitrary use of defamation clauses. 
The regulation of criminal defamation in ITE law has qualified as a complaint delict. The crime of defamation is delict with its object is selfesteem and dignity regarding the honour and reputation of a private person (Chazawi, 2009: 87). Honour and reputation are different things, although between the two have similarities in terms of the consequences resulting from the fall of a sense of self-esteem and dignity of the victim. Feelings of self-respect in defamation are limited to honour and dignity based on a system of moral values in society, not including the sense of dignity and honour in the realm of sexuality or human dignity. In contrast to the good name, which is based on a good view or assessment of the victims of society (Chazawi, 2009: 91). This defamation delict as a barrier to free speech, so that one's freedom must respect the person of another human being (M. Ali, 2010: 137). Delict of insults/contempt (including defamation) is still maintained because it is not in accordance with Indonesian culture full of civility and manners (Wibowo, 2013: 6-7), so Eddy O.S Hiariej called defamation as rechdelicten, not wetdelichten (Hiariej, 2009).

According to the author, defamation delict as a complaint delict that uses penal mediation as an alternative to dispute resolution will protect cyber media users from the shadow of criminal threats. If the shadow of this criminal threat continues to occur, it will curb cyber media users to convey/voice their opinions. Such restraint would disavow the values of Pancasila and the Indonesia Constitution of 1945 which gives citizens the right to express their opinions.

The application of the concept of penal mediation for complaints delict or defamation delict in the ITE field is not without obstacles. The author associated it with the obstacles to the application of penal mediation in general. First, the absence of legislation governing criminal cases can be done penal mediation. So far penal mediation is only regulated partially and limited as the author has stated in the above section. Not much different from what is in the ITE Law, which in it only explains the issue of complaints delict for defamation cases, is not in-depth about how the settlement mechanism. When the ITE Law which is a Lex Specialis does not regulate it, then the rules will return to the general rule, where the Indonesia Criminal Code and the Indonesia Criminal Procedure Code don't regulate the mediation procedure penally. It can be concluded that until now in Indonesia there is a legal vacuum regarding the application of mediation penal this, especially if applied to complaints delict and defamation delict in the ITE Law. If penal mediation is applied in such a state of legal vacancy, it can imply the continuing of a defamation case because penal mediation cannot be the basis for the cessation of the existing judicial process (Mulyadi, 2015: 175).

Second, it has not yet cultivated the application of the value of local wisdom in resolving criminal cases through penal mediation. It reminds the author of Lawrence M. Friedman's opinion on the effectiveness of the law, which includes elements of the substance of the law, the structure of the law 
and the culture of the law. The gap in the rules regarding penal mediation procedures in Indonesia, as described above, will be exacerbated if the legal culture in the community, as well as Indonesian law enforcement, is still thick with cultural values of retaliatory. The retributive culture as a result of the influence of Dutch colonialism culture, so that the character of Indonesian society is polite, friendly, forgiving, sensible, wise, a little bit has changed. Moreover, if the issue of news/information that is, in fact, incorrect and contains elements of contempt through ITE-based media facilities (which between parties do not meet each other and communicate directly), will further erode the cultures of consensus deliberation and tend to be individualistic. Similarly, the positivistic cultures adopted by most Indonesian law enforcement, which prioritizes formal legal settlements for criminal cases, both qualified as violations and complaints delict, as a result of the absence of a legal protection regarding the penal mediation procedure.

The obstacles are still growing, if the author relates to Eva Achjani Zulfa's opinion on the obstacles to the implementation of restorative justice in Indonesia (Mulyadi, 2015: 193-201). The author highlights the obstacles in terms of the position of victims and perpetrators in the defamation delicts in the field of ITE, because according to Eva Achjani Zulfa, for some types of criminal acts in determining the position of the perpetrator or victim is not an easy thing (Mulyadi, 2015: 194). Eva Achjani Zulfa's opinion may be true considering that in the perspective of victimology, Mandelshon, suggested that there are five types of victims in a crime, including victims who are victims of crimes because of their negligence, and victims who are more guilty of the perpetrators (Fajrin \& Triwijaya, 2019b: 72). There is also Sellin and Wolfgang's opinion on "mutual victimization", which means "the victim is the perpetrator himself" or Schafer's opinion which suggests the term "self victimizing victims" or "crimes committed by the victims themselves" (Fajrin \& Triwijaya, 2019b: 72). Not much different, Ezzat Abdel Fattah put forward the term "provocative victims" that is the victim becomes the trigger for the occurrence of criminal acts (Christianto, 2020: 177). These opinions illustrate that the occurrence of a crime is possible the role of the victim, so it is not easy to determine the position of the perpetrator or the victim. The issue is also vulnerable in dealing with complaints, especially defamation in the field of ITE. Because complaints delict are things that have personal/private values, which are quite difficult to identify the subject matter, so it needs to be smart and careful in parsing and determining the victim and the perpetrator. Because it does not close the possibility, a defamation case in the field of ITE that is being faced by law enforcement is the result of other unlawful acts that have chronologically occurred before.

Not until there are obstacles in terms of the position of the victim and the perpetrator. When it is clear who the perpetrator and the victim are, the next challenge is about the willingness of the perpetrator and the victim to sit together as the ideal communication pattern in penal mediation stated by Stefanie Trankle in the above section (Sapto Hermawan, 2019: 10). 
Considering this possibility, the role of law enforcement, especially the police, becomes very important as a mediator as well as a facilitator of solving a case through penal mediation. As the opinion of Adrianus Meliala that the role of the police as the starting gate of the criminal justice system, so it can be estimated that a case that has been started by ADR, will continue and end with the ADR anyway, rather than the ADR raised in the middle or at the end" (Mulyadi, 2015: 43). Especially in the case of complaints in the case of defamation in the field of ITE, where it is clear the position of the victim and the perpetrator, then the police must play a role as objectively and independently as possible, to realize the disputing parties, to be willing to sit together for consensus deliberation to resolve the issues faced. Legal substance as the entrance of the police implements the settlement of criminal cases outside the procedure, contained in Article 18 paragraph (1) of the Indonesia Law Number 2 year 2002 concerning the Police, in which the Police in carrying out its duties and authorities can act according to its assessment (Mulyadi, 2015: 198).

The obstacles as unravelled above can have implications for the settlement of defamation cases through the procedural means/mechanisms of criminal procedural law that will lead to the granting of criminal sanctions to perpetrators (Kukuh Tejomurti, 2020: 686). Whereas when referring to the opinion of Herbert L. Packer, those criminal sanctions are the main threat (primary threatener), where the threat in question can occur in several facets. First, in terms of the threat of sanctions for perpetrators. Punishing someone who is a perpetrator of defamation in the field of ITE can have a double effect. The dual effects in question include the limited right of freedom of the perpetrator that implies the life in question, and criminal sanctions negatively affect the process of socialization and reintegration of perpetrators in the community (as a result of penalization of criminal law as the opinion of labelling theory in criminology perspective).

Second, in terms of threats to the achievement of the goal of reforming the national criminal law. Broadly speaking, the purpose of Indonesia's criminal law in the future is to restore balance due to conflict / criminal acts, or referred to as a means of conflict resolution. The direction of the renewal of the national criminal law that thus places criminal sanctions is no longer a means of vilified or retaliating against the perpetrators as the view of retributivism. Criminalizing perpetrators of defamation is feared to prolong the conflict that occurs between the perpetrator and the victim. Given the rights of victims of defamation, in terms of improvement of dignity and selfesteem damaged by the actions of the perpetrators, is not achieved.

Third, in terms of threats to victims. Resolving defamation cases through procedural mechanisms aimed at criminalizing perpetrators, is not capable of resolving conflicts between the two conflicting parties. Moreover, defamation by the perpetrators has an impact on the damage to the victim's self-esteem and dignity in the eyes of the community, which is not able to be returned/repaired by the perpetrator. The unresolved loss of victims due to 
the application of procedural settlement methods will also correlate with other negative impacts, namely the unresolved conflict between the two parties that have the opportunity to enlarge the conflict to enter the realm of family relations of the two conflicting parties. Fourth, in terms of threats to the people of Indonesia. Examples of procedural defamation settlements will further lead the community to the paradigm of retributivism, namely punishing perpetrators to retaliate for their actions. This will further eliminate the characteristics and character of Indonesian society as a friendly, polite, forgiving, wise, and wise nation.

Fifth, in terms of threats to the right to free speech. The procedural defamation settlement is feared to curb free speech. Freedom of speech is a freedom of speech that refers to a right to free speech without any restrictive action (except in the case of spreading hatred) (Notanubun, 2014: 112). Procedural methods can give people the fear of expressing their opinions in public, whereas public opinion is permissible and is not part of the contempt if it meets the provisions outlined in the Indonesia law Number 9 year 1998 concerning Freedom of Speech in Public. Article 6 of Law Number 9 of 1998 requires that all people in matters of expressing an opinion must respect the rights and freedoms of others, respect the generally recognized moral rules, comply with the laws and regulations in force, maintain and maintain the security and public order, and maintain the integrity of national unity and unity.

Considering the possibility of bad that can occur as a result of legal procedural defamation settlement, then ideally the conflict that occurs can be resolved through penal mediation means. The potential for settlement of defamation delict in ITE through penal mediation means is possible for various reasons. First, penal mediation with a restorative justice approach has been understood and practised for a long time by the Indonesian people and has become part of the life of the nation as stated in 4th Pancasila. Second, defamation includes complaints delict, making it possible to be stopped through the procedure of retraction of the report when between the conflicting parties there has been a peace agreement. Third, penal mediation is intended to resolve conflicts between disputing parties, by seeking the truth of the case, pursuing remorse and apology from the perpetrator, and apology by the victim. Fourth, the state through law enforcement not only serves to enforce the law, but the main thing is to resolve the conflicts/disputes of the parties, including by finding the perpetrators who then sit with the victim to reach a peace agreement. Fifth, criminal law (both formal and material criminal law) will be the last resort of resolving a conflict (ultimum remidium).

The opportunity to resolve complaints about defamation in the field of ITE through penal mediation means, efforts are needed to overcome existing obstacles (as the author has described above). The main concern is the need for legal protection governing penal mediation or alternative dispute resolution (ADR) in general. 


\section{Conclusion}

Defamation is a field of ITE is a criminal act that is qualified as complaints delict, as the provisions of the Indonesia Law Number 19 year 2016 began to be regulated on complaints delict, namely in Article 45 paragraph (3) jo. paragraph (5). Changes in the type of delict for defamation, opening the opportunity to apply the method of settlement of cases through penal mediation method as one of the methods of settlement of cases outside the path of court procedures. Settlement through penal mediation mechanism can open opportunities for peace between the conflicting parties through a reconciliation agreement, to avoid the dropping of criminal sanctions on the perpetrators. Defamation in ITE law is a complaint that requires a complaint from the victim, because the object of the attack is personal, namely the dignity and self-esteem of the victim. Penal mediation as an alternative dispute resolution prioritizes the settlement of the conflict in a family that is in line with the values of Pancasila to resolve the prolonged conflict.

There are various obstacles to the application of penal mediation, not except in the settlement of defamation cases in the field of ITE. Among them are obstacles in the form of the absence of a technical legal protection for the implementation of penal mediation. Taking into account these obstacles, the rule of law regarding penal mediation is necessary as one of the efforts to resolve criminal cases in a non-litigation way. Efforts to solve criminal cases through penal mediation mechanisms and other non-litigation mechanisms can suppress efforts to solve criminal cases procedurally that lead to the dropping of criminal sanctions. Considering the direction of the renewal of Indonesia's national criminal law is no longer intended for mere retaliation or retaliatory (retributivism), but most importantly is to resolve or improve the consequences of a conflict / criminal act. Besides, penal mediation efforts as one of the means of settlement of cases outside the court (non-litigation) can be a solution to overcome the problem of overcapacity commonly experienced by correctional institutions in Indonesia.

\section{BIBLIOGRAPHY:}

Ali, A. (2012). Menguak Teori Hukum (Legal Theory) Dan Teori Peradilan (Judicial Prudence) Termasuk Interpretasi Undang-Undang (Legisprudence) - Vol.1 Pemahaman Awal. Jakarta: Kencana.

Ali, M. (2010). Pencemaran Nama Baik Melalui Sarana Informasi dan Transaksi $\begin{array}{llll}\text { Elektronik. Jurnal } & \text { Konstitusi, }\end{array}$ https:/ / doi.org/doi.org/10.31078/jk\%25x

Arief, B. N. (2008). Mediasi Penal Dalam Penyelesaian Perkara di Luar Pengadilan. Semarang: Penerbit UNDIP.

Aulia, M. Z. (2018). Hukum Pembangunan dari Mochtar Kusumaatmadja: Mengarahkan Pembangunan atau Mengabdi pada Pembangunan? Undang: Jurnal Hukum, 1(2), 363-392. https:/ / doi.org/10.22437/ujh.1.2.363-392 
Chazawi, A. (2009). Hukum Pidana Positif Penghinaan. Surabaya: Putra Media Nusantara.

Christianto, H. (2020). Konsep Hak Untuk Dilupakan Sebagai Pemenuhan Hak Korban Revenge Porn Berdasarkan Pasal 26 Undang-Undang Informasi Dan Transaksi Elektronik. Mimbar Hukum, 32(2), 175-192. https:// doi.org/10.22146/jmh.51110

CNN Indonesia. (2018). Kasus Augie Fantinus, Sembrono Gunakan Medsos Berujung Bui. Retrieved June 15, 2019, from CNN Indonesia website: https:// www.cnnindonesia.com/nasional/20181017070202-20339068/kasus-augie-fantinus-sembrono-gunakan-medsos-berujung-bui

CNN Indonesia. (2020). Polri Tangani 4.656 Kasus Siber, Pencemaran Nama Baik Dominan. Retrieved January 3, 2020, from CNN Indonesia website: https:/ / www.cnnindonesia.com/nasional/20201229094838-12-

587280/ polri-tangani-4656-kasus-siber-pencemaran-nama-baik-dominan

Faisal. (2011). Mediasi Penal Sebagai Alternatif Penyelesaian Perkara Pidana di Luar Pengadilan. Pranata Hukum, 6(1), 81-90.

Fajrin, Y. A., \& Triwijaya, A. F. (2019a). Arah Pembaharuan Hukum Pidana Indonesia di Tengah Pluralisme Hukum Indonesia. Ekspose: Jurnal Penelitian $\begin{array}{llll}\text { Hukum Dan } & \text { 734-740. }\end{array}$ https:// doi.org/10.30863/ekspose.v18i1.361

Fajrin, Y. A., \& Triwijaya, A. F. (2019b). Perempuan dalam Prostitusi: Konstruksi Pelindungan Hukum Terhadap Perempuan Indonesia dari Perspektif Yuridis dan Viktimologi (Women in prostitution: Construction of Legal Protection Towards Indonesian Women from a Juridical and Victimitarian Perspective). Negara Hukum: Membangun Hukum Untuk Keadilan Dan Kesejahteraan, 10(1), 67-88. https:/ / doi.org/10.22212/jnh.v10i1.1203

Harefa, B. (2015). Diversi Sebagai Perlindungan Hukum Terhadap Hak Asasi Anak Dalam Sistem Peradilan Pidana Anak Di Indonesia. Jurnal Komunikasi Hukum (JKH), 1(1), 1-13. https:/ / doi.org/10.23887/jkh.v1i1.5009

Hermawan, S. (2019). Pembabakan Kebijakan Lingkungan Hidup Nasional Berbasis Kearifan Lokal sebagai Strategi Adaptasi Menghadapi Perubahan Iklim. Majalah Ilmiah Cakrawala Hukum, 21(1), 1-11.

Hiariej, E. O. S. (2009). Memahami Pencemaran Nama Baik. Kompas. Retrieved from https:/ / malang.aji.or.id/2009/06/06/memahami-pencemaran-namabaik/

Iswara, I. M. A. M. (2017). Penguatan Kejaksaan Dalam Penanganan Perkara Pidana Melalui Plea Barganing. Jurnal Advokasi, 7(1), 24-37. Retrieved from http:/ /library1.nida.ac.th/termpaper6/sd/2554/19755.pdf

K Tejomurti, I Handayani. (2020). Application of the Proportionality Principle in the Credit Restructuring Policy for the SMEs Financial Performance During the Covid-19 Pandemic in Indonesia. The 2nd International Conference of Law, Government and Social Justice (ICOLGAS 2020). Atlantis Press

Kumendong, W. J. (2017). Kemungkinan Penyidikan Delik Aduan Tanpa Pengaduan. Jurnal Hukum Unsrat, 23(9), 53-62.

Laksana, A. W. (2017). Keadilan Restoratif Dalam Penyelesaian Perkara Anak 
Yang Berhadapan Dengan Hukum Dalam Sistem Peradilan Pidana Anak. Jurnal Pembaharuan Hukum, 4(1), 57-64. https:// doi.org/10.26532/jph.v4i1.1644

Lamintang, P. A. F. (2013). Dasar-dasar Hukum Pidana Indonesia. Bandung: Citra Aditya Bakti.

Lasmadi, S. (2011). Mediasi Penal Dalam Sistem Peradilan Pidana Indonesia. Inovatif, 4(5), 1-10.

Maerani, I. A. (2015). Implementasi Ide Keseimbangan Dalam Pembangunan Hukum Pidana Indonesia Berbasis Nilai-Nilai Pancasila. Jurnal Pembaharuan Hukum, 2(2), 329-338. https:/ / doi.org/dx.doi.org/10.26532/jph.v3i3.1364

Mulyadi, L. (2013a). Eksistensi Hukum Pidana Adat Di Indonesia: Pengkajian Asas, Norma, Teori, Praktik dan Prosedurnya. Jurnal Hukum Dan Peradilan, 2(2), 225-246. https:// doi.org/10.25216/jhp.2.2.2013.225-246

Mulyadi, L. (2013b). Mediasi Penal Dalam Sistem Peradilan Pidana Indonesia: Pengkajian Asas, Norma, Teori Dan Praktik. Yustisia, 2(1), 1-14. https:// doi.org/doi.org/10.20961/yustisia.v2i1.11054

Mulyadi, L. (2015). Mediasi Penal Dalam Sistem Peradilan Pidana Indonesia. Bandung: Alumni.

Mulyono, G. P. (2017). Kebijakan Formulasi Tindak Pidana Pencemaran Nama Baik Dalam Bidang Teknologi Informasi. Jurnal Cakrawala Hukum, 8(2), 160170. https://doi.org/10.26905/idjch.v8i2.1669

Nisa, C. U., \& Jaya, N. S. P. (2020). Penerapan Bentuk Mediasi Penal Dengan Pendekatan Keadilan Restoratif Dalam Sistem Peradilan Pidana Anak. Jurnal Komunikasi Hukum (JKH), 6(1), 253-265. https:// doi.org/dx.doi.org/10.23887/jkh.v6i1.23492

Notanubun, P. G. (2014). Tinjauan Yuridis Terhadap Kebebasan Berbicara Dalam Ketentuan Pasal 27 Ayat 3 UU Nomor 11 Tahun 2008 Tentang ITE Dalam Hubungan Dengan Pasal 28 UUD 1945. Mimbar Keadilan:Jurnal Ilmu Hukum, 12(2), 111-120.

Respationo, H. S., \& Hamzah, M. G. (2013). Putusan Hakim: Menuju Rasionalitas Hukum Refleksif Dalam Penegakan Hukum. Yustisia Jurnal Hukum, 2(2), 101-107. https://doi.org/10.20961/yustisia.v2i2.10194

Rumadan, I. (2013). Problem Lembaga Pemasyarakatan Di Indonesia Dan Reorientasi Tujuan Pemidanaan. Jurnal Hukum Dan Peradilan, 2(2), 263. https:// doi.org/10.25216/jhp.2.2.2013.263-276

Sahabuddin, S. (2014). Reorientasi Kebijakan Kriminal Dalam Menyelesaikan Kasus Ringan (Dari Due Process Model ke Reintegrative Model). Dinamika Hukum, 14(1), 162-175.

https:// doi.org/dx.doi.org/10.20884/1.jdh.2014.14.1.285

Santoso, S. (2015). Implementation Balancing Idea in the Development of Criminal Law in Indonesia. QIJIS (Qudus International Journal of Islamic Studies), 3(1), 1-22. https:/ / doi.org/dx.doi.org/10.21043/qijis.v3i1.1595

Saripudin, H. (2010). Kajian Terhadap Perda Bermasalah Dari Sudut Pandang HAM. Yuriska, 2(1), 13-27. https:/ / doi.org/doi.org/10.24903/yrs.v2i2.196 Sihotang, N. S. (2016). Penerapan Asas Sederhana, Cepat Dan Biaya Ringan Di 
Pengadilan Negeri Pekanbaru Berdasarkan Undang-Undang Nomor 48 Tahun 2009 Tentang Kekuasaan Kehakiman. Jurnal Online Mahasiswa Fakultas Hukum Universitas Riau, 3(2), 1-15.

Sullivan, D., \& Tifft, L. (2006). Handbook of Restorative Justice: A Global Perspective (1st ed.). Retrieved from https://www.taylorfrancis.com/books/9780203346822

Sunarso, S. (2012). Viktimologi Dalam Sistem Peradilan Pidana. Jakarta: Sinar Grafika.

Tami, N. D. P., \& Jaya, N. S. P. (2013). Studi Komparasi Pengaturan Pencemaran Nama Baik Menurut Hukum Pidana dan Hukum Perdata di Indonesia. Law Reform, 9(1), 106-123. https:/ / doi.org/doi.org/10.14710/lr.v9i1.12437

Tarigan, F. A. R. (2015). Upaya Diversi Bagi Anak Dalam Proses Peradilan. Lex Crimen, 4(5), 104-112.

Wahyuningsih, S. E. (2014). Urgensi Pembaharuan Hukum Pidana Materiel Indonesia Berdasarkan Nilai-Nilai Ketuhanan Yang Maha Esa. Jurnal Pembaharuan Hukum, 17-23. https://doi.org/dx.doi.org/10.26532/jph.v1i1.1457

Wibowo, A. (2013). Kebijakan Kriminalisasi Delik Pencemaran Nama Baik di Indonesia. Pandecta: Research Law Journal, 7(1), 1-12. https://doi.org/10.15294/pandecta.v7i1.2358

Yudianto, O. (2016). Karakter Hukum Pancasila Dalam Pembaharuan Hukum Pidana Indonesia. DIH: Jurnal Ilmu Hukum, 12(23), 35-44. https:// doi.org/doi.org/10.30996/dih.v12i23.890

Yusriando. (2015). Implementasi Mediasi Penal Sebagai Perwujudan Nilai- Nilai Pancasila Guna Mendukung Supremasi Hukum. Jurnal Pembaharuan Hukum, 2(1), 23-45. https:// doi.org/dx.doi.org/10.26532/jph.v2i1.1413 